\title{
Studies on the Localization of
}

\section{the Cardiac Glycoside Receptor}

\author{
Thomas W. Smith, Henry Wagner, Jr., John E. Markis, and \\ Michael Young \\ From the Laboratory of Physical Biochemistry, Massachusetts General Hospital, \\ and the Departments of Biological Chemistry, Medicine, and Pharmacology, \\ Harvard Medical School, Boston, Massachusetts 02114
}

A B S TRACT The purpose of this study was to see whether the receptor for cardiac glycosides might be localized upon or within the plasma membrane of digitalis-sensitive cells. Ouabain and digoxin were joined covalently to several large protein molecules. These macromolecular conjugates are too large to enter intact cells; consequently, any pharmacologic or biochemical effects which they display should arise from interaction with a cell surface receptor. Conjugates were tested in several cardiac glycoside-sensitive systems: $(a)$, contractility response of isolated cardiac muscle; $(b)$, active ${ }^{8} \mathrm{Rb}^{+}$uptake by red cells; $(c)$, enzymatic activity of isolated myocardial microsomal $\left(\mathrm{Na}^{+}+\mathrm{K}^{+}\right)$-activated adenosine triphosphatase (ATPase); and $(d)$, enzymatic activity of solubilized red cell $\left(\mathrm{Na}^{+}+\mathrm{K}^{+}\right)$-activated ATPase. Results demonstrated that in all of these systems, the macromolecular-glycoside conjugates were 100 - to 1000 -fold less active than the free glycosides. Careful chromatographic examination of the various conjugates revealed that they contained a small but persistent free cardiac glycoside contaminant. The amount of this species ranged from 0.1 to $1.0 \%$ of the total macromolecule-bound glycoside, and its presence fully explains the levels of biologic activity observed with the conjugates.

To try to minimize steric factors which could interfere with glycoside-receptor interaction, digoxin and ouabain were also coupled to macromolecule via long, flexible polyamide side-chains. These extended chain

An account of this work was presented before the American Society for Pharmacology and Experimental Therapeutics, Burlington, Vt., August 1971.

Dr. Smith was supported by special National Institutes of Health Postdoctoral Fellowship F03HE44673 and subsequently by an Established Investigatorship of the American Heart Association.

Received for publication 6 October 1971 and in revised form 28 December 1971. conjugates, in which the cardiac glycoside potentially lay some 30 A removed from the surface of the macromolecule, also exhibited negligible digitalis-like effects when tested upon isolated cardiac muscle, red cell ${ }^{\circledR} \mathrm{Rb}^{+}$ uptake, and enzymatic activity of cardiac microsomal $\left(\mathrm{Na}^{+}+\mathrm{K}^{+}\right)$-ATPase. However, the extended chain conjugates were fully active when examined with the solubilized red cell $\left(\mathrm{Na}^{+}+\mathrm{K}^{+}\right)$-ATPase system. To further ensure that the chemical reactions used to couple macromolecule to glycoside did not inactivate the drug, all conjugates were subjected to extensive proteolysis with Streptomyces griseus protease. These proteolytic digests exhibited full pharmacologic activity. Digoxin was also coupled to the tripeptide alanylglycylglycine, and the resulting conjugate was fully active.

Taken together, these results suggest that if the receptor(s) for cardiac glycosides is associated with the plasma membrane, then it may lie deep within it.

\section{INTRODUCTION}

Digitalis glycosides exert characteristic inotropic (1, 2) and electrophysiologic $(3,4)$ effects upon both the intact heart and isolated cardiac tissue preparations. Although the cardiac receptor (or receptors) which mediates the pharmacologic effects of these drugs has neither been isolated nor fully identified, recent evidence suggests that $\left(\mathrm{Na}^{+}+\mathrm{K}^{+}\right)$-activated adenosine triphosphatase (ATP phosphohydrolase, E.C. 3.6.1.3) plays a role in the mechanism of action of the cardioactive steroid glycosides (5-8). Thus, ouabain and digoxin bind to this membrane-associated enzyme, resulting in $(a)$, inhibition of $\left(\mathrm{Na}^{+}+\mathrm{K}^{+}\right)$-activated ATPase activity; and $(b)$, a decrease in the active transport of sodium and potassium ions across the cell membrane (9-12). It has been suggested that the 
positive inotropic effect may result from an increase in the amount of calcium ion available to the contractile element at the time of excitation-contraction coupling and that this effect might be mediated by cardiac glycoside binding to and/or inhibition of $\left(\mathrm{Na}^{+}+\mathrm{K}^{+}\right)$ATPase (13-16). Since this enzyme is believed to be a component of the sarcolemma (17), any digitalisinduced change in contractility would require an interaction between the drug and the cell plasma membrane. Of interest in this regard are studies of the squid giant axon (18) and the human erythrocyte ghost (19) which indicate that the cardiac glycoside receptor is accessible only from the external cell surface in these two digitalis-sensitive systems. The complex structure of the functioning myocardial cell (20) has precluded such direct assessment of the locus of digitalis action.

The studies described below were undertaken to try to localize directly the cellular receptor for digitalis, and to define further the nature of the interaction between cardiac glycosides and $\left(\mathrm{Na}^{+}+\mathrm{K}^{+}\right)$-ATPase. For this purpose, we have coupled digoxin and ouabain to several macromolecules. These high molecular weight conjugates would be expected to enter intact myocardial or red blood cells at very low rates, if at all $(21,22)$. Consequently, any pharmacologic activity which they display should arise from interaction with a cell surface receptor. The effects of these conjugates were studied in several digitalis-sensitive systems, including contractile response of isolated cardiac muscle, active rubidium $\left(\mathrm{Rb}^{+}\right)$uptake by erythrocytes, enzymatic activity of isolated myocardial microsomal $\left(\mathrm{Na}^{+}\right.$ $+\mathrm{K}^{+}$)-activated ATPase, and enzymatic activity of solubilized erythrocyte $\left(\mathrm{Na}^{+}+\mathrm{K}^{+}\right)$-activated ATPase.

\section{METHODS}

Reagents. Crystalline digoxin and randomly labeled digoxin ${ }^{-3} \mathrm{H} \quad(144 \mu \mathrm{Ci} / \mathrm{mg})$ were obtained from Burroughs Wellcome Co. (Research Triangle Park, N. C.) through the courtesy of Dr. Stanley T. Bloomfield. The degree of homogeneity of these compounds was examined by thinlayer chromatography on Silica gel G, using acetone: glacial acetic acid: cyclohexane $(49: 2: 49)$ as the developing solvent. Trichloroacetic acid-Chloramine-T (23) was used to identify nonradioactive digoxin, and the compound contained no detectable contaminant by this criterion. In the case of digoxin $-{ }^{3} \mathrm{H}, 1-\mathrm{cm}$ strips were subjected to liquid scintillation counting. $93 \%$ of counts ran as native digoxin. A minor secondary component $(3 \%)$ ran slightly ahead of the main peak, while $3 \%$ of counts were diffusely distributed behind the main peak. Less than $1 \%$ of counts remained at the origin. Crystalline ouabain was obtained from Eli Lilly and Company (Indianapolis, Ind.) through the courtesy of Dr. C. T. Chiu. Randomly labeled ouabain${ }^{3} \mathrm{H}$ (SA $11.7 \mathrm{Ci} / \mathrm{mmole}$ ), $\gamma_{-}{ }^{32} \mathrm{P}$ ATP (SA $12 \mathrm{Ci} / \mathrm{mmole}$ ), and ${ }^{80} \mathrm{RbCl}$ (SA $9.1 \mathrm{mCi} / \mathrm{mg}$ ) were obtained from New England Nuclear Corp. (Boston, Mass.) and were used without further purification. The ouabain $-{ }^{3} \mathrm{H}$ was subjected to thin-layer chromatography as described above, using a chloroform: methanol: water $(65: 30: 5)$ solvent system. $96 \%$ of counts were present in a single peak, with diffuse trailing of the remaining counts. No radioactive material remained at the origin. Bovine and human serum albumins (crystalline) and human serum albumin (fraction V powder) were obtained from Pentex Biochemical Inc. (Kankakee, Ill.), and were used without further purification except where noted. Myoglobin (equine heart, crystallized two times) was obtained from Calbiochem (San Diego, Calif.), and purified by gel filtration chromatography on Sephadex G-25 to remove low molecular weight contaminants. Streptomyces griseus protease (fraction V) was obtained from Sigma Chemical Co. (St. Louis, Mo.) All other reagents were of the highest available commercial grade and were used without further purification.

Analytical methods. Concentrations of digoxin- ${ }^{-} \mathrm{H}$, ouabain $-{ }^{8} \mathrm{H}$, and ${ }^{32} \mathrm{P}_{1}$ were measured with a Packard model 3003 liquid scintillation spectrometer (Packard Instrument Co., Inc., Downers Grove, I11.), using $10 \mathrm{ml}$ of a Triton $\mathrm{X}$-100-toluene $(2: 1 \mathrm{v} / \mathrm{v})$ based fluor containing $5.5 \mathrm{~g} \mathrm{2,5-}$ diphenyloxazole and $0.1 \mathrm{mg}$ 1,4-bis[2-(4-methyl-5-phenyloxazoly1)] benzene/litre.

Sodium dodecyl sulfate $(\mathrm{SDS})^{1}$ electrophoresis studies utilized the procedure of Weber and Osborne (24). Polyacrylamide gels containing $0.1 \%$ SDS were subjected to a 70 volt potential until bromphenol blue tracking dye had reached the bottom of the gel. Gels were run at $20^{\circ} \mathrm{C}$ in 0.05 M phosphate buffer, $\mathrm{pH}$ 7.0. Gels were fixed and stained overnight in $0.3 \%$ comassie brilliant blue dissolved in methanol : acetic acid: water $(227: 46: 227)$. Gels were destained electrophoretically in $7.5 \%(\mathrm{v} / \mathrm{v})$ acetic acid.

Ultraviolet absorption spectra were recorded with a Cary model 15 recording spectrophotometer (Cary Instruments, Monrovia, Calif.). Single wavelength measurements were made with a Zeiss PM QII spectrophotometer (Carl Zeiss, Inc., New York).

Protein concentrations were measured gravimetrically, or by the method of Lowry, Rosebrough, Farr, and Randall (25), with bovine serum albumin as standard. Amino acid analyses were performed by the method of Spackman, Stein, and Moore (26) with a Beckman model 120B amino acid analyzer (Beckman Instruments, Inc., Palo Alto, Calif.). Protein samples were hydrolyzed with $6 \mathrm{~N} \mathrm{HCl}$ (Mallinckrodt Chemical Works, St. Louis, Mo.) in sealed evacuated tubes for $18 \mathrm{hr}$ at $110^{\circ} \mathrm{C}$.

Ouabain and digoxin radioimmunoassay procedures were carried out as previously described $(27,28)$.

Synthesis and purification of protein-cardiac glycoside conjugates. Covalently coupled digoxin-human serum albumin (D-HSA), ouabain-human serum albumin (O-HSA), ouabain-bovine serum albumin (O-BSA), and digoxin-myoglobin ( $\mathrm{D}-\mathrm{Mgb}$ ) conjugates were prepared by modifications of the procedure described by Erlanger and Beiser (29) and adapted by Butler and Chen (30). Vicinal hydroxyl groups of the sugar moiety of the cardiac glycoside were oxidized to aldehydes by sodium metaperiodate. These

\footnotetext{
${ }^{1}$ Abbreviations used in this paper: D-ala-gly-gly, digoxinalanylglycylglycine; D-HSA, digoxin-human serum albumin; DA-S-DA-S-BSA, bovine serum albumin modified by addition of (succinyl-3,3'-diaminodipropylamine) 2 side chains; FDNB, 1-fluoro-2,4-dinitrobenzene; D-Mgb, digoxinmyoglobin; O-BSA, ouabain-bovine serum albumin; $\mathrm{O}-$ HSA, ouabain-human serum albumin; PBSG, phosphatebuffered saline with glucose; SDS. sodium dodecyl sulfate; TCA, trichloroacetic acid.
} 
reactive aldehydes were then coupled to amino groups of the carrier protein by Schiff-base formation, followed by reduction with sodium borohydride.

The coupling step was carried out for $2 \mathrm{hr}$ at $\mathrm{pH}$ 9.5-9.0. In some of the syntheses, a stoichiometric amount of sodium metaperiodate was used to oxidize the sugar, and the ethylene glycol step used to consume excess periodate was omitted. In all syntheses, suitable amounts of digoxin- ${ }^{8} \mathrm{H}$ or ouabain $-{ }^{3} \mathrm{H}$ were used to facilitate identification and quantitation of conjugated and free cardiac glycoside.

In a typical synthesis, $500 \mathrm{mg}$ ouabain and $0.125 \mathrm{mCi}$ ouabain- ${ }^{3} \mathrm{H}$ were dissolved in $30 \mathrm{ml}$ water. To this solution, $0.428 \mathrm{~g} \mathrm{NaIO}$, dissolved in $20 \mathrm{ml}$ water was added dropwise. After reaction for $30 \mathrm{~min}$ at room temperature, the oxidized ouabain was added dropwise to $500 \mathrm{mg}$ of protein dissolved in $25 \mathrm{ml}$ water, maintained at $\mathrm{pH} 9.5$ with $5 \%$ aqueous $\mathrm{K}_{2} \mathrm{CO}_{3}$. The reactants were magnetically stirred at room temperature. After $3 \mathrm{hr} 0.30 \mathrm{~g} \mathrm{NaBH}_{4}$, freshly dissolved in $20 \mathrm{ml}$ water, was added. $3 \mathrm{hr}$ later, the $\mathrm{pH}$ was lowered to 6.5 with concentrated formic acid. After $1 \mathrm{hr}$, sodium hydroxide was added to raise the $\mathrm{pH}$ to 8.5 and the reaction mixture dialyzed exhaustively against distilled water and lyophilized.

Two types of conjugates were prepared in which cardiac glycoside was not attached directly to the carrier protein but was extended from it by a long, flexible side-arm (Fig. 1). Two of these consisted of poly(D,L-alanyl) derivatives of human serum albumin and poly-L-lysine, synthesized by reaction with $\mathrm{N}$-carboxy $\mathrm{D}, \mathrm{L}$-alanine anhydrides according to the method of Schechter, Bauminger, Sela, Nachtigal, and Feldman (31). Amino acid analysis of the poly (D,Lalanyl)-HSA product before and after deamination (32) showed that an average of $50 \mathrm{D}, \mathrm{L}$-alanyl chains with a mean length of 9.5 alanyl residues had been attached per albumin molecule. The calculated molecular weight of the poly (D,Lalanyl)-HSA carrier was 98,000 and that of the poly (D,Lalanyl)-poly-L-lysine, 120,000 .

The other extended chain conjugate was synthesized as follows. Bovine serum albumin was succinylated according to the procedure of Habeeb, Cassidy, and Singer (33), using a 12-fold molar excess of succinic anhydride over protein amino groups. Reaction was allowed to proceed for $30 \mathrm{~min}$ at $0^{\circ} \mathrm{C}, \mathrm{pH} 8.0-8.5$. After succinylation, the protein was exhaustively dialyzed against distilled water at $4^{\circ} \mathrm{C}$ and lyophilized. The succinylated albumin was then dissolved in distilled water to a concentration of $5 \mathrm{mg} / \mathrm{ml}$ and adjusted to $\mathrm{pH} 5.0$ with $\mathrm{HCl}$. To this solution were then added a 50 -fold molar excess (relative to protein carboxyl groups) of $3,3^{\prime}$-diaminodipropylamine hydrochloride

$$
\begin{aligned}
& \mathrm{DA}-\mathrm{S}-\mathrm{DA} \text {-S-Albumin } \\
& \mathrm{H}-\left[\stackrel{\mathrm{H}}{\mathrm{N}} \mathrm{CH}_{2} \mathrm{CH}_{2} \mathrm{CH}_{2} \mathrm{NH} \mathrm{CH}_{2} \mathrm{CH}_{2} \mathrm{CH}_{2} \underset{\mathrm{H}}{\mathrm{N}} \mathrm{CH}_{2} \mathrm{CH}_{2} \mathrm{~N}_{2}\right] \text {-Albumin }
\end{aligned}
$$

Poly ( $D, L$-alanyl)-Albumin

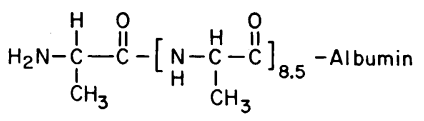

Figure 1 Structures of side-arms joined to serum albumin to produce a flexible extended chain. Cardiac glycosides were coupled to the terminal amino groups. (Synthesis of these derivatives is described in the text.)
TABLE I

Characterization of Intermediates in the Synthesis of $D A-S-D A-S-B S A$

\begin{tabular}{lc}
\hline \multicolumn{1}{c}{ Product } & $\begin{array}{c}\text { FDNB color yield } \\
(\% \text { of BSA color yield })\end{array}$ \\
\hline BSA & 100 \\
S-BSA & 17.3 \\
DA-S-BSA & 117.6 \\
S-DA-S-BSA & 16.0 \\
DA-S-DA-S-BSA & 119.1 \\
\hline
\end{tabular}

Products were reacted with excess FDNB, purified, and hydrolyzed as described in the text. Optical densities of the hydrolysates were measured at $360 \mathrm{~nm}$ and compared with the optical density of the hydrolyzed BSA derivative.

and a 30-fold molar excess of 1-cyclohexyl-3-(2-morpholinoethyl)-carbodiimide methyl $p$-toluenesulfonate, and $\mathrm{pH}$ readjusted to 5.0 (34). The solution was stirred overnight at room temperature.

After dialysis against distilled water and lyophilization, the product was resuccinylated and again reacted with the diamine by the same methods. The resulting compound is subsequently referred to as DA-S-DA-S-BSA. Extent of reaction at each stage of the synthesis was measured by reaction with fluorodinitrobenzene (35). Derivatized proteins were reacted with excess 1-fluoro-2,4-dinitrobenzene, hydrolyzed in $6 \mathrm{~N} \mathrm{HCl}$ for $18 \mathrm{hr}$ at $110^{\circ} \mathrm{C}$, and reactive amino groups determined by absorption at $360 \mathrm{~nm}$. Results of these analyses, which indicated a good coupling yield at each step, are summarized in Table I. Amino acid analysis of the final product before and after deamination showed that about 90 side-arms had been attached, resulting in a calculated molecular weight of 106,000 . Coupling of ouabain and digoxin to the amino groups of the poly (D,L-alanyl) carriers and of ouabain to the DA-S-DA-SBSA carrier was accomplished as described above.

Conjugates were purified by exhaustive dialysis, isoelectric precipitation (36), and repeated gel-sieve chromatography on polyacrylamide (Bio-Gel P-60) or cross-linked dextran (Sephadex G-75 and G-25) in neutral $0.1 \mathrm{M} \mathrm{NH}_{4}$ $\mathrm{HCO}_{3}$ and $0.01 \mathrm{M} \mathrm{Na}$ phosphate buffer systems. These columns were first calibrated with a mixture of protein carrier and free glycoside, and in all cases the two species were cleanly resolved by at least 20 fractions. $5-\mathrm{ml}$ column fractions were collected and digoxin $-{ }^{3} \mathrm{H}$ or ouabain $-{ }^{8} \mathrm{H}$ measured by liquid scintillation counting. Radioimmunoassay was also used to verify the identity, position, and concentration of free cardiac glycoside peaks in some column effluents.

To ensure that the sequence of reactions used to couple cardiac glycoside to carrier protein did not alter the biological activity of the glycoside, conjugates were treated with $S$. griseus protease. This proteolytic enzyme preparation cleaves proteins into free amino acids and di- and tripeptides (37). Conjugate $(10 \mathrm{mg} / \mathrm{ml})$ was exposed to $S$. griseus protease $(1 \mathrm{mg} / \mathrm{ml})$ in tris-buffered normal saline $(\mathrm{pH} 7)$ at $37^{\circ} \mathrm{C}$ for $14-16 \mathrm{hr}$. To exclude the possibility that presence of protease and/or the oligopeptide fragments released would affect the various assays, control digests of carrier proteins were prepared in the same way.

Digoxin was also coupled to the tripeptide alanylglycylglycine (Mann Research Labs, Inc., New York) by oxida- 
tion with NaIO, followed by Schiff-base formation and $\mathrm{NaBH}_{4}$ reduction as described for the macromolecular conjugation reactions. Digoxin-alanylglycylglycine (D-ala-glygly) was then separated from unreacted digoxin on a Dowex-1 column. Digoxin- ${ }^{8} \mathrm{H}$ tracer was used to identify the location of free and conjugated digoxin. After elution of all unreacted digoxin from the resin with $0.1 \mathrm{M}$ ammonium acetate at $\mathrm{pH} 6.4$, the tripeptide derivative was eluted with $0.1 \mathrm{M}$ acetic acid. Radioactivity measurements and amino acid analyses of this product revealed a molar ratio of digoxin:alanine: glycine of $1.0: 1.2: 2.5$.

\section{Assay procedures}

Four systems were used to measure the biochemical and pharmacologic effects of the macromolecular digoxin and ouabain conjugates.

Kitten papillary muscles and left atrial strips. The ability of digoxin and ouabain macromolecular conjugates to produce positive inotropic effects in cardiac muscle was tested. Right ventricular papillary muscles and left atrial strips from 400 - to $1200-\mathrm{g}$ kittens were used. Papillary muscles of less than $1.0 \mathrm{~mm}^{2}$ cross-sectional area were selected to ensure adequate oxygenation of central fibers (38). After the animals were killed by a sharp blow on the skull, their hearts were rapidly removed and immersed in a physiological salt solution at room temperature for dissection of papillary muscles or atrial preparations. Papillary muscles were removed together with a small button of adjacent ventricular wall and a short piece of chorda tendinea. Stretching of the muscle during dissection was carefully avoided since this impaired subsequent contractile performance.

The mural end of papillary muscle was clamped in a plastic electrode block, and the tendinous end was tied by a cotton thread to a stainless steel wire hook extending upward to a strain-gauge transducer (39). The long axis of the atrial strips was similarly fixed. Length-tension curves were determined for each papillary muscle and atrial strip, and each preparation was maintained for the remainder of the experiment at one-half of the resting tension necessary for maximal tension development. All preparations were allowed to equilibrate at this resting tension for at least $\frac{1}{2} \mathrm{hr}$ after developed tension had become stable.

The preparations were mounted in a $50 \mathrm{ml}$ organ bath containing a physiologic salt solution of the following composition in mmoles/liter: $\mathrm{Na}^{+}, 140 ; \mathrm{K}^{+}, 5 ; \mathrm{Ca}^{++}, 4.5$; $\mathrm{Mg}^{++}, 2 ; \mathrm{Cl}^{-}, 98.5 ; \mathrm{SO}_{4}=, 2 ; \mathrm{HCO}_{3}{ }^{-}$and $\mathrm{H}_{2} \mathrm{CO}_{3}, 29$; $\mathrm{HPO}_{4}=$ and $\mathrm{H}_{2} \mathrm{PO}_{4}^{-}, 2$; fumarate, 5 ; pyruvate, 5 ; L-glutamate, 5; glucose, 10. Demineralized water, double-distilled in glass, was used. The bath solution was continuously oxygenated and stirred by a gas mixture of $95 \% \mathrm{O}_{2}$ and $5 \%$ $\mathrm{CO}_{2}$. After equilibration with this mixture the bath $\mathrm{pH}$ was 7.4. All experiments were carried out at $32.5^{\circ} \mathrm{C}$.

A driving stimulus was applied through a pair of punctate platinum electrodes in contact with the nontendinous end of the papillary muscle or left atrial strip. Muscles were driven at 2-sec intervals by square-wave pulses of $5 \mathrm{msec}$ duration. Stimulus intensity was just above threshold in order to prevent release of norepinephrine from adrenergic endings $(40,41)$. Isometric tension was measured with strain-gauge transducers (Statham G7B-1-350, Statham Instruments, Inc., Oxnard, Calif.) and recorded on a direct-writing oscillograph (Sanborn 964, Sanborn Div., Hewlett-Packard Co., Palo Alto, Calif.) equipped with 350-1100 carrier preamplifiers. Base line active tension de- velopment was between 0.4 and $1.0 \mathrm{~g}$ in all papillary muscle preparations studied.

The volume of cardiac glycoside conjugate or free cardiac glycoside solution added never exceeded $1.0 \%$ of the total bath volume. Foaming produced by the addition of protein to the bath was controlled by the use of a loose silicone-coated stainless steel wire mesh inserted in the top of the open side of the muscle chamber. This device produced no detectable change in resting or developed tension over periods greater than $4 \mathrm{hr}$. All interventions were carried out on at least four muscle preparations. Changes in developed tension were measured only when no further effect was observed for at least $\frac{1}{2} \mathrm{hr}$ after a plateau in response was reached.

Erythrocyte ${ }^{86} \mathrm{Rb}^{+}$uptake. Measurements of ${ }^{86} \mathrm{Rb}^{+}$uptake by washed human erythrocytes were made by a modification of the method of Lowenstein (42). Freshly drawn, heparinized human blood was centrifuged at $1000 \mathrm{~g}$ for 15 min and the serum and buffy coat removed. The red cells were washed three times with $0.01 \mathrm{M} \mathrm{Na}$ phosphate, $0.15 \mathrm{M}$ $\mathrm{NaCl}, \mathrm{pH} 7.4$, containing $1 \mathrm{mg} / \mathrm{ml}$ glucose (PBSG). Preparations were used the same day. In a typical experiment, $0.6-\mathrm{ml}$ packed red cells was mixed with $0.4 \mathrm{ml}$ PBSG containing varying concentrations of free or conjugated cardiac glycosides and preincubated for $2 \mathrm{hr}$ at $20^{\circ} \mathrm{C}$. The uptake assay was started by addition of ${ }^{\circ} \mathrm{RbCl}$ and the cell suspension was gently shaken at $37^{\circ} \mathrm{C}$ in a water bath for $2 \mathrm{hr}$. The cells were then chilled in an ice bath after addition of $3 \mathrm{ml}$ of ice-cold PBSG, and separated by centrifugation for $15 \mathrm{~min}$ at $2000 \mathrm{~g}$ followed by careful removal of the supernatant phase. This washing procedure was repeated three times. The uptake of ${ }^{86} \mathrm{Rb}^{+}$ was measured with a Nuclear-Chicago gamma spectrometer (Nuclear-Chicago Corp., Des Plaines, Ill.).

Canine myocardial microsomal $\left(\mathrm{Na}^{+}+\mathrm{K}^{+}\right)$-activated ATPase. ATPase was prepared by the method of Akera, Larsen, and Brody (43) with the following modifications kindly suggested by Dr. Brody. Dithiothreitol $\left(10^{-4} \mathrm{M}\right)$ was included in all of the solutions used in the preparation of the enzyme. Minced left ventricular muscle was homogenized twice in a Dounce glass ball homogenizer, first with a 0.012 inch tolerance pestle, then with a 0.004 inch tolerance pestle, before the first centrifugation. ATPase activity was measured in duplicate by the liberation of inorganic phosphate using a modification of the method of Akera and Brody (44). The assay medium contained $50 \mathrm{~mm}$ Tris$\mathrm{HCl}, 5 \mathrm{mM} \mathrm{MgCl}, \mathrm{pH} \mathrm{7.5}$, and for assay of $\left(\mathrm{Na}^{+}+\mathrm{K}^{+}\right)-$ activated ATPase, $100 \mathrm{~mm} \mathrm{NaCl}$ and $15 \mathrm{~mm} \mathrm{KCl}$. Free or conjugated cardiac glycosides were added in several final concentrations, and these solutions (containing $100 \mu \mathrm{g}$ of microsomal protein) were preincubated for $5 \mathrm{~min}$ at $37^{\circ} \mathrm{C}$. The reaction was started by addition of Tris-ATP to a final concentration of $5 \mathrm{~mm}$. After $15 \mathrm{~min}$, the reaction was stopped by addition of ice-cold trichloroacetic acid (TCA) to a final concentration of $10 \%$. The precipitated protein was spun down, and portions of the supernatant solution assayed for inorganic phosphate by the method of Fiske and Subbarow (45). All activities were corrected for spontaneous hydrolysis of ATP by subtraction of the amount of inorganic phosphate released by samples treated exactly as in the corresponding enzyme assay, but to which enzyme was added just before addition of TCA. Each enzyme preparation was used for assay purposes within 48 $\mathrm{hr}$ of its preparation, since significant loss of activity was noted after storage for longer periods. The specific activity of preparations used was $10 \pm 2 \mu$ moles $P_{1}$ released $/ \mathrm{mg}$ 
TABLE II

Chemical Characteristics of Cardiac Glycoside Conjugates

\begin{tabular}{|c|c|c|}
\hline $\begin{array}{c}\text { Conjugate } \\
\text { [Abbreviation] }\end{array}$ & $\begin{array}{c}\text { Moles cardiac glycoside } \\
\text { coupled per mole } \\
\text { carrier }\end{array}$ & Free contaminant* \\
\hline Diroxin-human serum albumin (D-HSA) & & $\%$ \\
\hline $\begin{array}{l}\text { Digoxin-human serum albumin (D-HSA) } \\
\text { Ouabain-human serum albumin (O-HSA) }\end{array}$ & $\begin{array}{l}4-5 f \\
4-5 t\end{array}$ & $0.2-0.6 \pm$ \\
\hline Ouabain-bovine serum albumin (O-BSA) & $4-5 \ddagger$ & $0.1-0.6 \ddagger$ \\
\hline Digoxin-myoglobin (D-Mgb) & 1.4 & 0.9 \\
\hline Ouabain-poly ( $\mathrm{D}, \mathrm{L}$-alanyl)-human serum albumin & & \\
\hline [O-poly (D,L-alanyl)-HSA] & $4-5 \ddagger$ & 1 \\
\hline $\begin{array}{l}\text { Digoxin-poly (D,L-alanyl)-poly-L- } \\
\text { lysine }[D-p o l y(D, L-a l a n y l) \text { poly-L- }\end{array}$ & & \\
\hline lysine] & 17 & 1 \\
\hline Digoxin-poly ( $\mathrm{D}, \mathrm{L}$-alanyl)-human serum albumin & & \\
\hline [D-poly (D,L-alanyl)-HSA] & $4-5 \ddagger$ & 1 \\
\hline Ouabain-( $3,3^{\prime}$-diaminodipropylamino-succinyl $)_{2}$-bovine serum albumin & & \\
\hline (O-DA-S-DA-S-BSA) & 4.6 & 0.7 \\
\hline Digoxin-alanylglycylglycine (D-ala-gly-gly) & 0.83 & - \\
\hline
\end{tabular}

* Per cent of total counts applied to the column which emerged in the salt volume after repeated gel filtration chromatography.

$\ddagger$ Values in two conjugate preparations studied.

protein per hr, of which $81 \pm 2 \%$ was $\mathrm{Na}^{+}-\mathrm{K}^{+}$dependent and inhibitable in the presence of $10^{-4} \mathrm{M}$ ouabain.

Human erythrocyte solubilized $\left(\mathrm{Na}^{+}+\mathrm{K}^{+}\right)-$ATPase. $\left(\mathrm{Na}^{+}+\mathrm{K}^{+}\right)-\mathrm{ATPase}$ was prepared by a slight modification of the method of Dunham and Hoffman (46). Fresh heparinized human blood was centrifuged at $15,000 \mathrm{~g}$ for $5 \mathrm{~min}$. The serum and buffy coat were removed, and the packed red cells added to 10 vol of cold hemolysis buffer $(0.1 \mathrm{~mm}$ $\mathrm{Na}_{2}$ EDTA, adjusted to $\mathrm{pH} 7.4$ with Tris), shaken vigorously by hand, and allowed to stand for $5 \mathrm{~min}$. They were then centrifuged at $20,000 \mathrm{~g}$ for $20 \mathrm{~min}$, and the ghosts washed with $0.1 \mathrm{~mm} \mathrm{Na}_{2} \mathrm{EDTA}, 15 \mathrm{~mm} \mathrm{NaCl}$, adjusted to $\mathrm{pH} 7.4$ with Tris and centrifuged at $20,000 \mathrm{~g}$ for 20 min. This washing procedure was repeated four times. At this stage the ghosts, which were faint pink in color, were rapidly frozen and thawed five times and again centrifuged at $20,000 \mathrm{~g}$ for $20 \mathrm{~min}$. The nearly white ghosts were then solubilized with SDS. In a typical experiment, 4 $\mathrm{ml}$ of packed ghosts were mixed with $6 \mathrm{ml}$ of $0.2 \%(\mathrm{w} / \mathrm{v})$ SDS in $0.5 \mathrm{~mm} \mathrm{Na}_{2}$ EDTA, $0.5 \mathrm{~mm}$ Tris-HCl, $\mathrm{pH} 8.5$, and dialyzed against several changes of $0.5 \mathrm{~mm} \mathrm{Na}{ }_{2}$ EDTA, 0.5 $\mathrm{mm}$ Tris- $\mathrm{HCl}, \mathrm{pH} 8.5$ for periods of $48-72 \mathrm{hr}$. The SDStreated ghosts were then centrifuged at $140,000 \mathrm{~g}$ for $1 \mathrm{hr}$. The supernatant solution from this centrifugation was used as the "soluble" ATPase.

$\left(\mathrm{Na}^{+}+\mathrm{K}^{+}\right)$-ATPase activity of this preparation was assayed according to Dunham and Hoffman (46) with minor modifications. The assay solution contained $40 \mathrm{mM}$ $\mathrm{NaCl}, 20 \mathrm{~mm} \mathrm{KCl}, 1.25 \mathrm{mM} \mathrm{MgCl}, 0.25 \mathrm{~mm} \mathrm{Na} \mathrm{NaDTA}_{2}$, $10 \mathrm{~mm}$ Tris- $\mathrm{HCl}, \mathrm{pH}$ 8.5. All measurements were performed in duplicate. The enzyme (final concentration 100 $\mu \mathrm{g}$ protein $/ \mathrm{ml}$ ) was incubated with free or conjugated cardiac glycoside for $30 \mathrm{~min}$ at $20^{\circ} \mathrm{C}$. Reaction was started by addition of $\mathrm{Na}_{2} \mathrm{ATP}$ (containing $0.2 \mu \mathrm{Ci}$ tracer ATP- $\gamma-$ ${ }^{22} \mathrm{P}$ ) to a final concentration of $1 \mathrm{mM}$. Enzyme samples were incubated at $37^{\circ} \mathrm{C}$ for $2 \mathrm{hr}$, at which time reaction was stopped by addition of $3 \mathrm{vol}$ of a cold $4 \%$ suspension of Norit-A in $0.1 \mathrm{M} \mathrm{HCl}, 1 \mathrm{~mm} \mathrm{NaH} \mathrm{PO}_{4}, 1 \mathrm{~mm} \mathrm{NaP} \mathrm{O}_{7}$. After standing $5 \mathrm{~min}$, samples were centrifuged at $3500 \mathrm{~g}$ for $15 \mathrm{~min}$ and portions of the supernatant solution counted for ${ }^{32} \mathrm{P}_{1}$. Enzyme activity values were corrected for spontaneous hydrolysis of ATP and for displacement of ATP from charcoal by protein or ouabain by the inclusion of samples in which the enzyme was added just before the reaction was stopped.

\section{RESULTS}

Characterization of cardiac glycoside conjugates. Table II summarizes data which characterize the several conjugates which were synthesized. Synthesis of conjugates of digoxin or ouabain coupled directly to $\epsilon$-amino groups of lysine routinely gave products after purification which contained between 4 and 5 moles of cardiac glycoside per mole of serum albumin, as measured by incorporation of ouabain- ${ }^{8} \mathrm{H}$ or digoxin- ${ }^{8} \mathrm{H}$ of known specific activity. Similar results were obtained by spectral measurement in concentrated sulfuric acid $(47,36)$. The serum albumin-poly (D,L-alanine)-ouabain conjugate also contained 4-5 moles of cardiac glycoside per mole of carrier, while the digoxin conjugate with poly(D,L-alanyl)-poly-L-lysine contained 17 digoxin residues/mole. The purified O-DA-S-DA-S-BSA conjugate contained 4.6 moles of ouabain/mole of carrier.

Despite the several purification methods used to eliminate free cardiac glycoside from the glycoside-protein conjugates, all conjugates studied were invariably found to contain a small amount of low molecular weight radioactive material which emerged in the salt volume

Site of Action of the Cardiac Glycosides

1781 


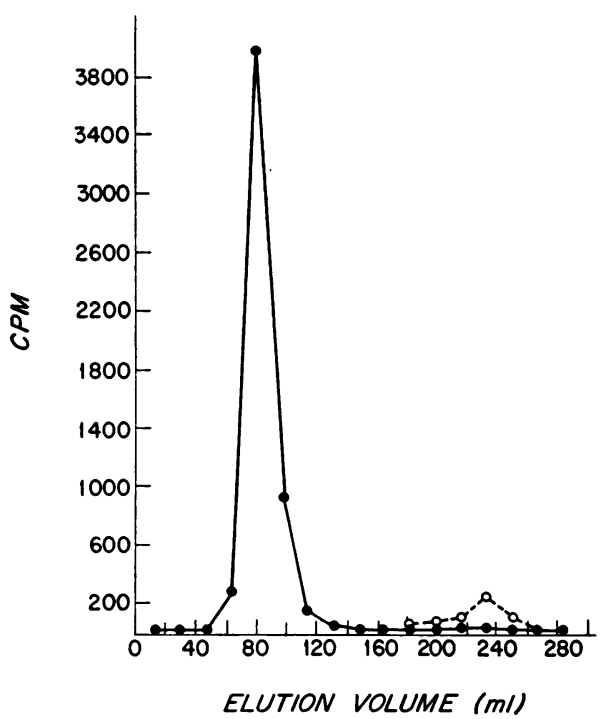

Figure 2 Separation of O-BSA from free ouabain contaminant by chromatography on Sephadex G-75. The $2 \times 50$ $\mathrm{cm}$ column was eluted with $0.01 \mathrm{M} \mathrm{Na}$ phosphate buffer, $\mathrm{pH} 8.0$, at $4^{\circ} \mathrm{C}$. The sample shown here had been chromatographed twice previously with identical results. $50-\mu 1$ portions of each fraction were counted (- -1$)$. In the region of the salt volume, 1-ml samples were counted (O---O) to show more clearly the presence of free ouabain.

on gel filtration chromatography in a manner identical with free, unreacted cardiac glycoside (Fig. 2). Even after seven cycles of gel filtration followed by concentration of the conjugate fraction by lyophilization, this low molecular weight material was still present in amounts varying from 0.1 to $1.0 \%$ of the total cardiac glycoside content present in the sample (as calculated from area measurements of the two tritium-containing peaks corresponding to conjugated and free ouabain or digoxin). This material contained the expected amounts of ouabain or digoxin by radioimmunoassay. Thin-layer chromatography revealed the presence of two components-one with $R_{\mathbf{f}}$ corresponding to free native ouabain or digoxin, and another which did not move from the origin. The latter component absorbed in the ultraviolet $(\lambda \max =265 \mathrm{~nm})$, and was ninhydrin positive. Amino acid analysis of acid hydrolysates of the second peak revealed an amino acid composition quite different from that of the carrier protein.

The possibility that small amounts of free cardiac glycoside contaminants repeatedly chromatographed with protein carrier due to noncovalent binding was eliminated by observation of complete separation of simultaneously chromatographed protein carrier and native, free tritiated cardiac glycoside under the conditions used for conjugate purifications. The low molecular weight material eluted from gel filtration columns in the salt volume, comprising both free digoxin or ouabain and oligopeptides, will subsequently be referred to as free cardiac glycoside.

To evaluate the possibility that persistent presence of free cardiac glycoside was due to cleavage of unstable hemithioacetal linkages between cysteine sulfhydryl groups and aldehyde groups of the NaIO-oxidized glycoside, myoglobin (which contains no cysteine or cystine residues) was used as carrier. This conjugate demonstrated the same degree of slight but persistent instability noted above. Another possible source of the low molecular weight material was peptide bond cleavage, which might arise either during $\mathrm{NaBH}_{4}$ reduction or from a protease contaminant present in the protein carriers. Treatment of chromatographically-purified crystalline myoglobin with $\mathrm{NaBH}_{4}$ under the conditions used in the actual coupling reaction gave a product which, on SDS gel electrophoresis, showed one major band corresponding to intact myoglobin and at least three bands of lower molecular weight material. Untreated myoglobin yielded a single band. SDS gel electrophoresis of the second peak from D-HSA showed several low molecular weight components which probably represented peptide fragments of the carrier protein molecule.

In further efforts to remove this free glycoside, conjugates were chromatographed on columns of Sephadex G-75 in $8 \mathrm{~m}$ urea. This was done with the idea that proteolytic contaminants cochromatographing with the carrier proteins (48) might be irreversibly denatured by urea. The conjugate peak was dialyzed to remove urea, lyophilyzed, and rechromatographed on Sephadex G-75. This procedure had no effect on the amount of free cardiac glycoside found in subsequent chromatographic analyses of these conjugates. In addition, a conjugate was synthesized using as a carrier protein bovine serum albumin which had been precipitated with $10 \%$ aqueous trichloroacetic acid, dissolved in $95 \%$ ethanol, and dialyzed against distilled water (49). After this procedure (also intended to inactivate possible proteolytic enzyme contaminants), conjugates were obtained which showed the same amount of free glycoside contaminant previously noted.

In the studies to be described, conjugates were used which had been rechromatographed to stable minimal levels of free cardiac glycoside contaminant. In all cases, conjugate preparations were used which exhibited 0.1-1.0\% free contaminant (Table II). Thus, in interpreting results, the percentage of free cardiac glycoside contaminant for each conjugate shown in Table II must be considered.

Effects of macromolecular conjugates upon isolated kitten papillary muscles and atrial strips. As summarized in Table III, D-HSA, O-HSA, D-poly(D,L-ala- 
TABLE III

Summary of Isolated Cardiac Muscle Studies

\begin{tabular}{|c|c|c|c|c|}
\hline Cardiac glycoside preparation* & $\begin{array}{c}\text { Molar } \\
\text { concentrationf }\end{array}$ & $\begin{array}{c}\text { Tissue } \\
\text { preparation }\end{array}$ & $\begin{array}{l}\text { Number of } \\
\text { muscle } \\
\text { specimens } \\
\text { studied }\end{array}$ & $\begin{array}{c}\text { Mean \% change } \\
\text { in active } \\
\text { tension developed } \\
\text { 土SEM }\end{array}$ \\
\hline D-HSA & $2.4 \times 10^{-6}$ & KPM & 4 & $0 \pm 2$ \\
\hline O-HSA & $\begin{array}{l}2.4 \times 10^{-6} \\
2.4 \times 10^{-6}\end{array}$ & $\begin{array}{l}\text { KLAS } \\
\text { KPM }\end{array}$ & $\begin{array}{l}4 \\
4\end{array}$ & $\begin{array}{l}+2 \pm 4 \\
-1 \pm 3\end{array}$ \\
\hline \multirow{3}{*}{$\begin{array}{l}\text { D-poly (D,L-alanyl)-HSA } \\
\text { O-poly (D,L-alanyl)-HSA }\end{array}$} & $4 \times 10^{-6}$ & KPM & 4 & $-4 \pm 5$ \\
\hline & $2 \times 10^{-6}$ & KPM & 4 & $+3 \pm 6$ \\
\hline & $2 \times 10^{-6}$ & KLAS & 2 & $-2 \pm 5$ \\
\hline \multirow{2}{*}{ O-DA-S-DA-S-BSA } & $4 \times 10^{-6}$ & KPM & 3 & $0 \pm 4$ \\
\hline & $4 \times 10^{-6}$ & KLAS & 2 & $+4 \pm 4$ \\
\hline D-poly (D,L-alanyl)-poly-L-lysine & $5 \times 10^{-6}$ & KPM & 4 & $-5 \pm 7$ \\
\hline D-ala-gly-gly & $\begin{array}{l}5 \times 10^{-7} \\
5 \times 10^{-7}\end{array}$ & $\begin{array}{l}\text { KPM } \\
\text { KLAS }\end{array}$ & $\begin{array}{l}3 \\
4\end{array}$ & $\begin{array}{c}+78 \pm 7 \\
+120 \pm 14\end{array}$ \\
\hline \multirow[t]{2}{*}{ Digoxin\| } & $5 \times 10^{-7}$ & KPM & 4 & $+56 \pm 10$ \\
\hline & $5 \times 10^{-7}$ & KLAS & 2 & $+105 \pm 18$ \\
\hline \multirow[t]{2}{*}{ Ouabain\| } & $2 \times 10^{-7}$ & KPM & 4 & $+90 \pm 15$ \\
\hline & $2 \times 10^{-7}$ & KLAS & 2 & $+138 \pm 20$ \\
\hline D-HSA/protease I & $5 \times 10^{-7}$ & KPM & 4 & $+70 \pm 12$ \\
\hline \multirow[t]{2}{*}{ O-HSA/protease $\mathbb{I}$} & $4 \times 10^{-7}$ & KPM & 2 & $+215 \pm 30$ \\
\hline & $4 \times 10^{-7}$ & KLAS & 2 & $+240 \pm 17$ \\
\hline \multirow[t]{2}{*}{ O-poly (D,L-alanyl)-HSA/protease } & $4 \times 10^{-7}$ & KPM & 3 & $+160 \pm 20$ \\
\hline & $4 \times 10^{-7}$ & KLAS & 2 & $+200 \pm 28$ \\
\hline \multirow[t]{2}{*}{ O-DA-S-DA-S-BSA/protease } & $2 \times 10^{-7}$ & KPM & 2 & $+90 \pm 15$ \\
\hline & $2 \times 10^{-7}$ & KLAS & 2 & $+152 \pm 20$ \\
\hline
\end{tabular}

* Abbreviations as in Table II.

$\ddagger$ Conjugate molarities are expressed in terms of carrier molecule concentration.

$\S \mathrm{KPM}$, kitten papillary muscles; KLAS, kitten left atrial strips.

|| In presence of carrier, which by itself produced no change in resting or active tension.

I Addition of equivalent amounts of protease-digested carrier produced no significant change in resting or active tension.

nyl)-HSA, O-poly (D,L-alanyl)-HSA, D-poly (D,L,-alanyl)-poly-L-lysine, and O-DA-S-DA-S-BSA produced no positive inotropic responses or rhythm disturbances with exposure to conjugate concentrations as high as $5 \times 10^{-6} \mathrm{M}$ for periods up to $4 \mathrm{hr}$. After this time period, the same muscle preparations were exposed to free ouabain or digoxin. An increase in active tension at least $50 \%$ above base line levels was observed in response to $5 \times 10^{-7} \mathrm{M}$ free digoxin or an increase of at least $90 \%$ with $2 \times 10^{-7} \mathrm{M}$ free ouabain in the presence of carrier protein. The carrier compounds alone exerted no significant effects on contractility in the concentrations used in these studies. At high conjugate concentrations, the effects of the small amounts of free cardiac glycoside contaminants were manifest, resulting in positive inotropic responses quantitatively similar to those obtained with equivalent free concentrations of native ouabain or digoxin. The positive inotropic responses observed in the presence of these higher concentrations could always be quantitatively accounted for solely on the basis of the free glycoside contaminant. In marked contrast to the intact macromolecular forms, S. griseus protease digests of cardiac glycoside conjugates produced typical positive inotropic responses in isolated cardiac muscle (see Table III). These responses were equivalent in magnitude to those obtained with the same concentrations of native free digoxin or ouabain. The tripeptide derivative of digoxin, D-ala-gly-gly, also produced a marked increase in active tension development, somewhat greater in magnitude than that obtained with similar concentrations of native digoxin. Thus, since small proteolytic fragments of the conjugates as well as purified D-alagly-gly produced full inotropic responses, we conclude 
that the sequence of reactions used in the glycosidemacromolecule coupling process has not altered the potential biological activity of the drug.

Human erythrocyte ${ }^{86} \mathrm{Rb}^{+}$uptake. None of the direct conjugates of digoxin or ouabain to albumin (D-HSA, O-HSA, O-BSA, D-Mgb) inhibited red cell ${ }^{88} \mathrm{Rb}^{+}$uptake to an extent greater than that expected from the amount of free cardiac glycoside contaminant. Moreover, the conjugates to extended chain carriers (D-poly(D,L-alanyl)-HSA, O-poly (D,L-alanyl)-HSA, O-DAS-DA-S-BSA) showed no activity in this preparation. As shown in Fig. 3, the concentration-response curve of O-DA-S-DA-S-BSA was shifted to the right by a concentration factor of 100 . This activity level is fully accounted for by the $1 \%$ free contaminant present in this preparation. The concentration-response curve for O-BSA, which contained only $0.1 \%$ free contaminant, was shifted to the right by a factor of 1000 , as shown in Fig. 4. Nevertheless, after extensive proteolytic degradation of the carrier protein with $S$. griseus protease, full ${ }^{8} \mathrm{Rb}^{+}$uptake inhibition occurred at concentrations comparable with those of free ouabain (Fig. 4).

Control experiments demonstrated that the BSA and DA-S-DA-S-BSA carriers did not inhibit ${ }^{8} \mathrm{Rb}^{+}$uptake except at very high concentrations $(10 \mathrm{mg} / \mathrm{ml})$, nor did they affect the inhibition produced by free ouabain.

Canine myocardial microsomal $\left(\mathrm{Na}^{+}+\mathrm{K}^{+}\right)$-activated ATPase. The cardiac glycoside-sensitive microsomal ATPase was not inhibited by O-BSA, D-poly(D,L-ala-

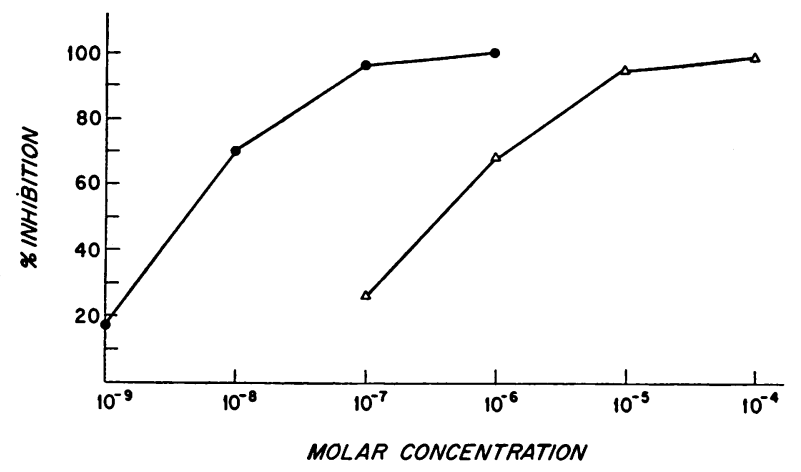

FIgURE 3 Inhibition of human erythrocyte ${ }^{8} \mathrm{Rb}^{+}$uptake by free ouabain (๑) and by O-DA-S-DA-S-BSA $(0.7 \%$ free contaminant $(\triangle)$. The concentration-response curve of the conjugate is shifted about 100 -fold to the right, as would be expected on the basis of the amount of free ouabain contaminant. Each point is the mean of duplicate determinations which agreed with $5 \%$ or less. $\mathrm{RbCl}$ concentration was $0.08 \mathrm{~mm}$. Maximal uptake in the absence of inhibitor was $4.7 \times 10^{-8}$ moles $\mathrm{Rb} / \mathrm{ml}$ packed $\mathrm{RBC}$ per $\mathrm{hr}$. $100 \%$ inhibition was taken as the degree of inhibition (82\% of maximal uptake) which occurred in the presence of $10^{-4}$ ouabain. Values were corrected for the $1-2 \%$ of counts retained after wash cycles when ${ }^{86} \mathrm{Rb}$ was added immediately before washing.

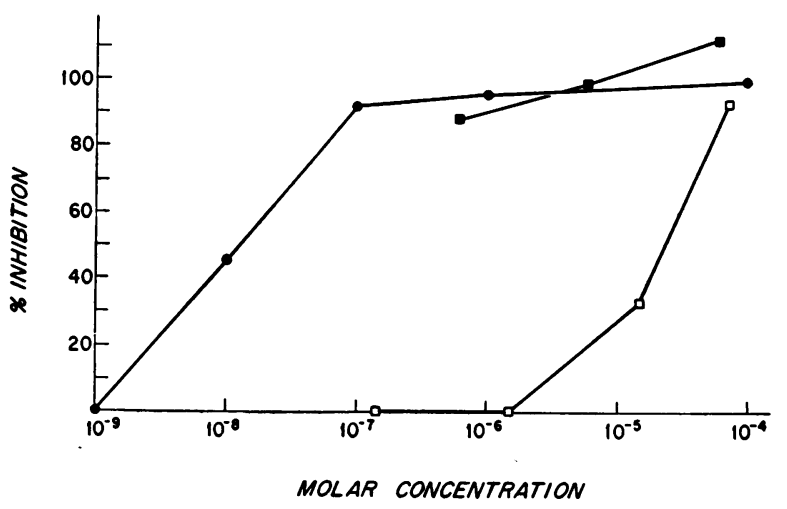

FIgURE 4 Inhibition of human erythrocyte ${ }^{86} \mathrm{Rb}^{+}$uptake by free ouabain (๑), O-BSA $(0.1 \%$ free ouabain contaminant) ( $\square$ ) and by $S$. griseus protease digest of $\mathrm{O}$ BSA (a). The inhibition in the presence of intact conjugate is entirely accounted for by the amount of free contaminant, while the inhibition by the proteolytic digest is comparable with that of similar concentrations of free ouabain. Each point is the mean of duplicate determinations which differed by $6 \%$ or less. $\mathrm{RbCl}$ concentration was 0.1 mM. Calculations as in Fig. 3; maximal uptake in the absence of inhibitor was $7.2 \times 10^{-8}$ moles $\mathrm{Rb} / \mathrm{ml}$ packed $\mathrm{RBC}$ per hr.

nyl)-HSA or O-DA-S-DA-S-BSA beyond the extent expected from the amount of free cardiac glycoside present in each preparation. As in the erythrocyte ${ }^{80} \mathrm{Rb}^{+}$ uptake studies, concentration-response curves for enzyme inhibition showed that at least 100 -fold higher concentrations of conjugate were required relative to free glycoside to produce a given degree of enzyme inhibition. The inhibition that was observed was fully accounted for by the $1 \%$ free contaminant. Even less inhibition occurred with preparations such as O-BSA which contained still less free cardiac glycoside. Protease digests of the O-BSA conjugate were fully active in this system. The ouabain and ouabain-peptide fragments resulting from protease digestion produced the same degree of enzyme inhibition observed with equivalent molar concentrations of native free ouabain. The $50 \%$ inhibitory concentration for ouabain plus ouabain peptides from protease-treated conjugates and for native free ouabain was $5.1 \times 10^{-7} \mathrm{M}$. This value is in reasonable agreement with the half-inhibitory ouabain concentration of $7.9 \times 10^{-7} \mathrm{M}$ reported by Akera et al. (43).

Solubilized erythrocyte $\left(\mathrm{Na}^{+}+\mathrm{K}^{+}\right)$-ATPase. The nonextended conjugate O-BSA inhibited ATPase activity to an extent only slightly greated than that expected from its $0.7 \%$ free ouabain contaminant. However, O-DA-S-DA-S-BSA was fully active in inhibiting the solubilized $\left(\mathrm{Na}^{+}+\mathrm{K}^{+}\right)$-ATPase; its concentrationresponse curve was closely similar to that of free ouabain. Results of a typical experiment are shown in Fig. 
5. The extended chain carrier without ouabain was unable to inhibit this ATPase within a comparable concentration range, indicating that the observed inhibition was the result of the ouabain coupled to the carrier.

\section{DISCUSSION}

The best-defined biochemical effect of the cardiac glycosides is their ability to inhibit the $\left(\mathrm{Na}^{+}+\mathrm{K}^{+}\right)$-activated ATPase which is involved in the active transport of sodium and potassium across cell membranes (9, 50, 51). It has been suggested that the $\left(\mathrm{Na}^{+}+\mathrm{K}^{+}\right)$-ATPase system is the pharmacologic receptor for cardiac glycosides $(5)$, and recent studies $(7,8)$ have shown that $\left(\mathrm{Na}^{+}+\mathrm{K}^{+}\right)$-ATPase of canine myocardial microsomal preparations is indeed inhibited at positive inotropic but subtoxic doses of ouabain. Others have reported experiments consistent with a cardiac glycoside effect on certain characteristics of calcium binding by the sarcoplasmic reticulum $(52,53)$, although this has not been a consistent finding at concentrations sufficient to produce significant inhibition of $\left(\mathrm{Na}^{+}+\mathrm{K}^{+}\right)$ATPase (15). Both of these mechanisms might serve to increase the availability of calcium to the contractile element at the time of excitation-contraction coupling, resulting in a positive inotropic response $(6,13,14$, 54-56).

Insight into the mechanism of cardiac glycoside effects on the heart might be gained if one could define the location of the receptor which mediates these actions. Radioautography has yielded conflicting results with regard to the ultrastructural localization of radioactively labeled digitalis glycosides in cardiac tissue (57). Observations of inhibition of ouabain binding and inhibition of ouabain effect by extracellular potassium ion were initially interpreted as suggesting a competition between potassium and ouabain for a site at the external surface of the cell $(58,59,10)$. More recent evidence, however, indicates that potassium and ouabain do not compete directly for the same binding site (19, $11,60,61)$.

Two studies provide direct evidence that the cardiac glycoside-sensitive portion of the $\mathrm{Na}^{+}-\mathrm{K}^{+}$transport mechanism is accessible only from the external surface of the cell membrane. Caldwell and Keynes showed that ouabain inhibition of $\mathrm{Na}^{+}$flux in the squid giant axon occurs only when the drug is present in the external milieu. No effect was observed at a 100 -fold higher concentration placed inside the axon (18). Hoffman, studying erythrocyte ghosts, found that cells lysed in the presence of the cardioactive aglycone strophanthidin (and resealed with the agent on the inside) showed no inhibition of active sodium efflux, whereas the strophanthidin-containing lysate from these cells was able to inhibit sodium transport when added to

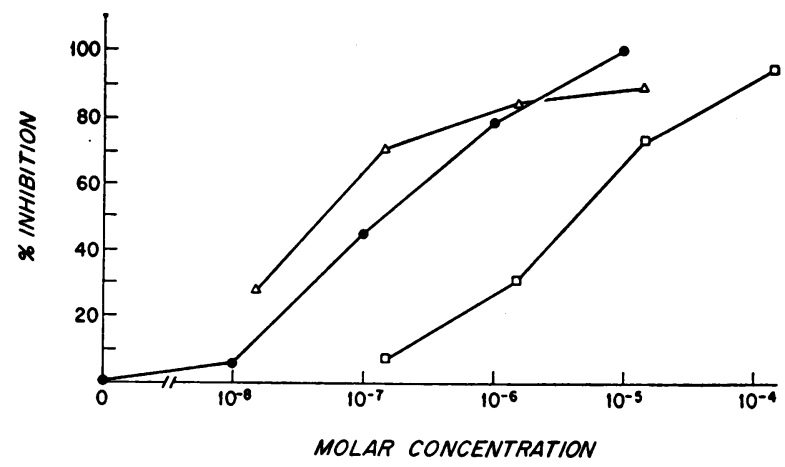

FIgURE 5 Inhibition of solubilized human erythrocyte $\left(\mathrm{Na}^{+}\right.$ $+\mathrm{K}^{+}$)-activated ATPase by ouabain ( $\bullet$ ), O-DA-S-DA-SBSA $(0.7 \%$ free ouabain contaminant) $(\Delta)$, and O-BSA ( $0.6 \%$ free contaminant) ( $\square$ ). Each point is the mean of duplicate determinations agreeing within $8 \%$ or less. The extended chain conjugate is fully active compared with free ouabain while ouabain coupled directly to serum albumin inhibits the enzyme to a comparable extent only at 80-fold higher concentrations. Total specific ATPase activity in the absence of any inhibitor was 1.05 pmoles $\mathrm{Pi}$ released/ $\mu \mathrm{g}$ protein per $\mathrm{hr}$, of which $90 \%$ was inhibitable by $10^{-4} \mathrm{M}$ ouabain. (Per cent inhibition is relative to that produced by $10^{-4} \mathrm{M}$ ouabain taken as $100 \%$.)

intact cells and available at the external cell surface (19).

Because of the structural complexity of the myocardial cell (20), no direct demonstration of the locus of digitalis action has been possible. The approach employed in the studies reported here is based on the idea that an agent which interacts with a receptor at the external cell surface may still do so when covalently coupled to a macromolecular carrier too large to penetrate the plasma membrane. This general approach enabled Cuatrecasas (62) to obtain evidence that the insulin receptor is localized on the cell surface.

In the studies presented above, digoxin was covalently linked to bovine and human serum albumin to test the hypothesis that the receptor which mediates inotropic and/or electrophysiologic effects might be localized on or within the cell membrane in such a way to permit interaction with these macromolecular glycoside conjugates. All of these derivatives, however, were found to have digitalis-like effects only when present at 100 - or 1000 -fold greater molar concentrations than those of native digoxin in each system studied.

Because of the possibility that, once coupled, the relatively apolar genin portion of digoxin might lie spatially within a relatively hindered hydrophobic environment of the albumin molecule, conjugates of the more polar compound ouabain were prepared. Yet, these conjugates also did not exert biochemical or pharmacologic effects which were quantitatively com- 
parable with those observed with free glycosides. Detailed analysis of these conjugate preparations then revealed the presence of a minor component of low molecular weight which emerged from cross-linked dextran and polyacrylamide gel columns in the salt volume and contained free digoxin or ouabain by thin-layer chromatography and by radioimmunoassay. The latter method yielded free cardiac glycoside concentrations which were in agreement with those calculated from the direct measurement of radioactivity. Material present in this fraction also contained amino acids and, in all likelihood, oligopeptides of digoxin or ouabain since about $50 \%$ of counts in labeled digoxin or ouabain remained at the origin in thin-layer chromatography systems with a mobile organic phase. The amino acid composition of this fraction differed substantially from that of native serum albumin, and this feature excludes the possibility of an anomalously slowrunning fraction of the intact conjugate during gel filtration. Since this free glycoside fraction persisted, quantitatively unchanged, after seven serial gel filtration chromatography steps, it appears that a slow cleavage of cardiac glycoside and/or oligopeptides of cardiac glycoside from protein carrier occurs. Slight instability of the covalent bond between cardiac glycoside and carrier cannot be excluded on the basis of these data.

Reduction with $\mathrm{NaBH}_{4}$ is known to cleave peptide bonds under certain conditions (63) as we found with myoglobin, but this would not account for the persistent low molecular weight contaminant after multiple high resolution gel filtration steps. The possibility that a proteolytic enzyme contaminant present in the carrier protein (48) might persist through the various purification steps was also considered. Presence of the same amount of free cardiac glycoside and oligopeptide fragments after treatment of the conjugate with $8 \mathrm{M}$ urea or of the carrier with $10 \%$ TCA indicates that such a proteolytic contaminant would have to be unusually resistant to these denaturants. The further possibility that instability occurred due to cardiac glycoside molecules linked to sulfhydryl groups through hemithioacetal linkages was also considered. Yet the digoxinmyoglobin conjugate, which contained no sulfhydryl groups, exhibited the same instability pattern as the albumin derivative. Thus, we are unable to explain satisfactorily the presence of free cardiac glycoside in these conjugate preparations after repeated gel filtration chromatography.

The lack of activity attributable to intact albumin conjugates of digoxin or ouabain in each system studied raised the possibility that the sequence of coupling reactions employed might have altered the intrinsic properties of the ouabain or digoxin molecule. This was ruled out in all cases by the observation that extensive proteolytic digests of each conjugate were as active as free, native cardiac glycoside on a mole for mole basis in isolated cardiac muscle experiments as well as myocardial microsomal $\left(\mathrm{Na}^{+}+\mathrm{K}^{+}\right)$-ATPase and erythrocyte ${ }^{80} \mathrm{Rb}^{+}$uptake studies. In addition, digoxin coupled to the tripeptide alanylglycylglycine produced inotropic responses in isolated cardiac tissue which were at least equivalent to those of native digoxin, and somewhat more rapid in onset.

Thus, conjugation of digoxin or ouabain directly to serum albumin blocks interaction between cardiac glycoside and the molecular species to which it binds in isolated cardiac muscle preparations, intact erythrocytes, myocardial microsomal $\left(\mathrm{Na}^{+}+\mathrm{K}^{+}\right)$-activated ATPase, and solubilized erythrocyte $\left(\mathrm{Na}^{+}+\mathrm{K}^{+}\right)$-activated ATPase. The possibility of exclusion from the cellular compartment within which the receptor resides in the case of isolated cardiac muscle cannot be excluded. A preliminary report (64) of a positive inotropic response in cultured heart cells to a digoxinalbumin conjugate may reflect an effect of unrecognized free cardiac glycoside contaminant, or possibly a system with different receptor topography and responsiveness.

The lack of interaction between cellular receptor or in vitro ATPase preparations and the direct conjugates of digoxin or ouabain to serum albumin has a counterpart in certain affinity chromatography systems where ligands coupled directly to a solid support matrix are unable to interact with the enzyme-binding site. In such systems, attachment of the ligand to the solid support by a long, flexible chain of atoms sometimes enables the ligand to interact readily with the enzyme-binding site $(65,66,34)$. For this reason, the extended chain derivatives of serum albumin shown in Fig. 1 were synthesized and digoxin or ouabain coupled to terminal amino groups. Yet these extended chain conjugates also exhibited no effect on isolated cardiac muscle contractility, erythrocyte ${ }^{\approx \mathrm{Rb}^{+}}$uptake, or myocardial microsomal $\left(\mathrm{Na}^{+}+\mathrm{K}^{+}\right)$-ATPase which could not be fully accounted for by the magnitude of the free cardiac glycoside contaminant. This finding suggests that an affinity chromatography approach to the isolation of a sarcolemmal fraction or microsomal $\left(\mathrm{Na}^{+}+\right.$ $\mathrm{K}^{+}$)-ATPase using an immobilized cardiac glycoside would not be likely to succeed unless some more effective means were found to overcome the factors which interfere with ligand-enzyme interaction.

To try to diminish further steric factors which might interfere with the interaction between cardiac glycoside and $\left(\mathrm{Na}^{+}+\mathrm{K}^{+}\right)$-ATPase, solubilized red cell $\left(\mathrm{Na}^{+}+\right.$ $\mathrm{K}^{+}$)-ATPase was prepared (46). As described in the results section, when ouabain was linked directly to macromolecule, the resulting conjugate produced little 
if any inhibition of the soluble enzyme. On the other hand, the extended chain conjugate O-DA-S-DA-SBSA does inhibit solubilized erythrocyte $\left(\mathrm{Na}^{+}+\mathrm{K}^{+}\right)$ATPase, and the concentration-response curve is closely similar to that of native ouabain. Thus, the combined effects of at least partially freeing the $\left(\mathrm{Na}^{+}+\mathrm{K}^{+}\right)$ATPase enzyme complex from its membrane environment and of extending the ouabain inhibitor from the carrier molecule via a long, flexible side chain appear to allow an interaction to occur which neither condition alone will permit. An alternative possibility is that the addition of the extended side chains, terminating for the most part in primary amino groups, results in a polycation which through charge effects might facilitate interaction between macromolecular ouabain and $\left(\mathrm{Na}^{+}\right.$ $+\mathrm{K}^{+}$)-ATPase.

In light of evidence that the cardiac glycoside sensitive portion of the erythrocyte $\mathrm{Na}^{+}-\mathrm{K}^{+}$pump is accessible only from the outer cell surface (19), the inability of macromolecule-glycoside conjugates to inhibit ${ }^{80} \mathrm{Rb}$ transport supports the idea that steric factors prevent interaction between conjugate and cellular receptor. The cardiac glycoside sensitive $\left(\mathrm{Na}^{+}+\mathrm{K}^{+}\right)$ATPase of cardiac muscle, which is thought to reside in sarcolemma $(7,17)$, may well share steric constraints similar to those of the red cell membrane. Hence, the failure of digoxin and ouabain conjugates to exert evident electrophysiologic or positive inotropic effects on isolated cardiac tissue cannot be considered a valid argument against the hypothesis that the receptor is $\left(\mathrm{Na}^{+}+\mathrm{K}^{+}\right)$-ATPase or some other sarcolemmal component. This point is underscored by the inability of the macromolecular cardiac glycoside conjugates studied to inhibit isolated myocardial microsomal $\left(\mathrm{Na}^{+}+\mathrm{K}^{+}\right)$ATPase. Indeed, the striking parallelism between the ability of various preparations to inhibit myocardial microsomal $\left(\mathrm{Na}^{+}+\mathrm{K}^{+}\right)$-ATPase and to produce increased contractile strength in isolated cardiac tissue lends indirect support to the concept of a link between $\left(\mathrm{Na}^{+}+\mathrm{K}^{+}\right)$-ATPase inhibition and positive inotropy.

Although the data summarized above do not provide direct evidence for localization of the cardiac glycoside receptor, studies with the extended chain ouabain conjugate O-DA-S-DA-S-BSA reveal that $(a)$, this compound does inhibit solubilized red cell $\left(\mathrm{Na}^{+}+\mathrm{K}^{+}\right)$activated ATPase; and $(b)$, proteolytic digests of the conjugate as well as the tripeptide D-ala-gly-gly are fully active in all systems examined. Consequently, the fact that this conjugate is inactive upon cardiac muscle preparations, intact red cells, and myocardial microsomal $\left(\mathrm{Na}^{+}+\mathrm{K}^{+}\right)$-activated ATPase may be due to an insufficiently long side chain extension from the albumin backbone.

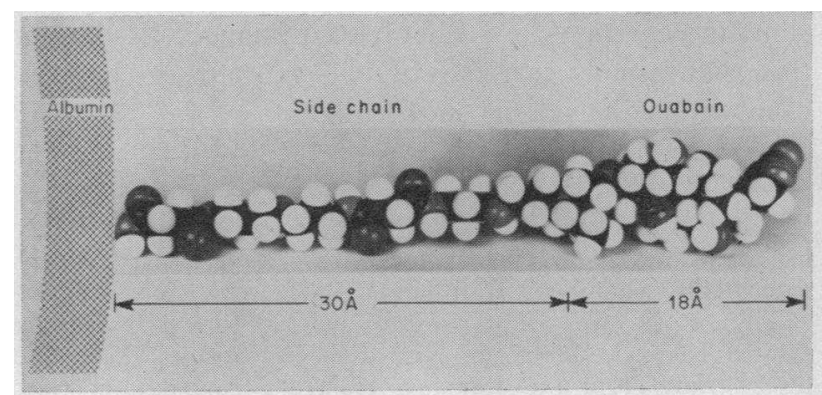

FiguRE 6 Corey-Pauling-Koltun space-filling model of ouabain linked to bovine serum albumin by an extended (succinyl-3,3'-diaminodipropylamine $)_{2}$ side chain.

Fig. 6 illustrates a Corey-Pauling-Koltun (CPK) space-filling model of ouabain attached to the (succinyl-3,3'-diaminodipropylamine) ${ }_{2}$ side chain shown in Fig. 1. Since periodate oxidation of ouabain would be expected to split the sugar ring between $\mathrm{C}_{2}^{\prime}$ and $\mathrm{C}^{\prime}$ (and to release $\mathrm{C}_{3}^{\prime}$ as formic acid) (67) the terminal$\mathrm{NH}_{2}$ function of the side chain has been joined to the sugar $\mathrm{C}_{2}^{\prime}$ and $\mathrm{C}_{4}^{\prime}$ carbon atoms to form a cyclic six-membered morpholino derivative. (See references 68 , 69, and 27 for a discussion of the chemistry pertinent to this reaction.) This model is shown in its fully extended conformation, and its overall end-to-end length is about $48 \mathrm{~A}$. The length of the side chain itself is $30 \mathrm{~A}$. On the other hand, there is no reason to think that ouabain extends $30 \mathrm{~A}$ from the surface of the albumin backbone, since the side chain is flexible and displays considerable rotational freedom. (It should be pointed out here that the secondary amine of $3,3^{\prime}$-diaminodipropylamine would be expected to react with the succinyl group during synthesis of the side chain extensions. The model of Fig. 6 depicts only reaction with primary amino groups to produce the longest side-arm extensions.)

Now let us consider the ultrastructure of the cardiac sarcolemmal membrane. Electron microscopic studies indicate that this structure is a complex composed of a 90 A thick plasma membrane which is coated on the outside by a 500 A thick polysaccharide-protein layer (20). This structure also is the limiting membrane of the transverse tubular system. These tubules are approximately $1500-2000 \mathrm{~A}$ in diameter (20) and are thus large enough to permit the extended albumin conjugate to enter them. The limiting plasma membrane of the erythrocyte is approximately $60 \mathrm{~A}$ thick (19). If the receptor for the cardiac glycosides is membrane bound, and if the macromolecular conjugates described above are potentially active (as studies with solubilized ATPase, proteolytic digests, and the model tripeptide conjugate suggest), then it may be that the side chain extension depicted in Fig. 6 is simply too

Site of Action of the Cardiac Glycosides

1787 
short to penetrate the membrane far enough. If so, then this would imply that the digitalis receptor(s) may lie deep within the plasma membrane.

\section{ACKNOWLEDGMENTS}

We are grateful to Dr. Jan Koch-Weser for the extended use of some of his instruments. This paper is gratefully dedicated to Mr. W. C. Ratliff.

This work was supported by NIH Research Career Award K03-AM-18565, by NIH Research grant AM-09404, by a grant from the John A. Hartford Foundation, Inc., and by grant 70870 from the American Heart Association to Dr. Young; also by a grant from the Massachusetts Heart Association and by NIH Research grant 1R01HE14325 to Dr. Smith.

\section{REFERENCES}

1. Mason, D. T., J. F. Spann, Jr., and R. Zelis. 1969. New developments in the understanding of the actions of the digitalis glycosides. Progr. Cardiovasc. Dis. 11: 443.

2. Greenspan, K., and R. E. Edmands. 1969. The inotropic effects of digitalis. In Digitalis. C. Fisch and B. Surawicz, editors. Grune \& Stratton, Inc., New York. 65.

3. Hoffman, B. F., and D. H. Singer. 1964. Effects of digitalis on electrical activity of cardiac fibers. Progr. Cardiovasc. Dis. $7: 226$.

4. Hoffman, B. F. 1971. Effects of digitalis on electrical activity of cardiac membranes. In Basic and Clinical Pharmacology of Digitalis. B. Marks and A. Weissler, editors. Charles C. Thomas, Publisher, Springfield, Ill. (In press).

5. Repke, K. 1963. Metabolism of cardiac glycosides. Proc. Int. Pharmacol. Meet. 3 : 47.

6. Glynn, I. M. 1969. The effects of cardiac glycosides on metabolism and ion fluxes. In Digitalis. C. Fisch and B. Surawicz, editors. Grune \& Stratton, Inc., New York. 30.

7. Besch, H. R., Jr., J. C. Allen, G. Glick, and A. Schwartz. 1970. Correlation between the inotropic action of ouabain and its effects on subcellular enzyme systems from canine myocardium. J. Pharmacol. Exp. Ther. 171: 1.

8. Akera, T., F. S. Larsen, and T. M. Brody. 1970. Correlation of cardiac sodium-and potassium-activated ATPase activity with ouabain-induced inotropic stimu1ation. J. Pharmacol. Exp. Ther. 173: 145.

9. Glynn, I. M. 1964. The action of cardiac glycosides on ion movements. Pharmacol. Rev. 16: 381.

10. Page, E. 1964. The actions of cardiac glycosides on heart muscle cells. Circulation. 30: 237.

11. Albers, R. W., G. J. Koval, and G. J. Siegel. 1968. Studies on the interaction of ouabain and other cardioactive steroids with sodium-potassium-activated adenosine triphosphatase. Mol. Pharmacol. 4: 324.

12. Dunham, P. B., and J. F. Hoffman. 1971. Active cation transport and ouabain binding in high potassium and low potassium red blood cells of sheep. J. Gen. Physiol. 58: 94.

13. Langer, G. A. 1968. Ion fluxes in cardiac excitation and contraction and their relation to myocardial contractility. Physiol. Rev. 48: 708.

14. Baker, P. F., M. P. Blaustein, A. L. Hodgkin, and R. A. Steinhardt. 1969. The influence of calcium on sodium efflux in squid axons. J. Physiol. (London). 200: 431.
15. Schwartz, A., J. C. Allen, and S. Harigaya. 1969. Possible involvement of cardiac $\mathrm{Na}^{+}, \mathrm{K}^{+}$-adenosine triphosphatase in the mechanism of cardiac glycosides. $J$. Pharmacol. Exp. Ther. 168: 31.

16. Langer, G. A. 1970. The role of sodium ion in the regulation of myocardial contractility. J. Mol. Cell. Cardiol. $1: 203$.

17. Stam, A. C., Jr., W. B. Weglicki, Jr., D. Feldman, J. C. Shelburne, and E. H. Sonnenblick. 1970. Canine myocardial sarcolemma-Its preparation and enzymatic activity. J. Mol. Cell Cardiol. 1: 117.

18. Caldwell, P. C., and R. D. Keynes. 1959. The effect of ouabain on the effiux of sodium from a squid giant axon. J. Physiol. (London). 148: 8P.

19. Hoffman, J. F. 1966. The red cell membrane and the transport of sodium and potassium. Amer. J. Med. 41: 666.

20. Fawcett, D. W., and N. S. McNutt. 1969. The ultrastructure of the cat myocardium. J. Cell Biol. 42: 1 .

21. Page, E. 1962. Cat heart muscle in vitro. III. The extracellular space. J. Gen. Physiol. 46: 201.

22. Ryser, H. J.-P. 1968. Uptake of protein by mammalian cells: an underdeveloped area. Science (Washington). 159: 390 .

23. Waldi, D. 1959. Eine neue systematische Analyse von Alkaloiden mit hilfe der Papierchromatographie. Arch. Pharm. Ber. Dtsch. Pharm. Ges. 292: 206.

24. Weber, K., and M. Osborne. 1969. The reliability of molecular weight determinations by dodecyl sulfatepolyacrylamide gel electrophoresis. J. Biol. Chem. 244: 4406.

25. Lowry, O. H., N. J. Rosebrough, A. L. Farr, and R. M. Randall. 1951. Protein measurement with the Folin phenol reagent. J. Biol. Chem. 193: 265.

26. Spackman, D. H., W. H. Stein, and S. Moore. 1958 Automatic recording apparatus for use in the chromatography of amino acids. Anal. Chem. 30: 1190.

27. Smith, T. W., 1972. Ouabain-specific antibodies: immunochemical properties and reversal of $\mathrm{Na}^{+}, \mathrm{K}^{+}$-activated adenosine triphosphatase inhibition. J. Clin. Invest. 51: 1583.

28. Smith, T. W., V. P. Butler, Jr., and E. Haber. 1969 Determination of therapeutic and toxic serum digoxin concentrations by radioimmunoassay. N. Engl. J. Med. 281: 1212 .

29. Erlanger, B. F., and S. M. Beiser. 1964. Antibodies specific for ribonucleosides and ribonucleotides and their reaction with DNA. Proc. Nat. Acad. Sci. U. S. A. 52: 68 .

30. Butler, V. P., Jr., and J. P. Chen. 1967. Digoxin-specific antibodies. Proc. Nat. Acad. Sci. U. S. A. 57: 71.

31. Schechter, I., S. Bauminger, M. Sela, D. Nachtigal, and M. Feldman. 1964. Immune response to polypeptidyl proteins in rabbits tolerant to the protein carriers. Immunochemistry. 1: 249.

32. Anfinsen, C. B., M. Sela, and J. P. Cooke. 1962. The reversible reduction of disulfide bonds in poly-alanyl ribonuclease. J. Biol. Chem. 237: 1825.

33. Habeeb, A. F. S. A., H. G. Cassidy, and S. J. Singer. 1958. Molecular structural effects produced in proteins by reaction with succinic anhydride. Biochim. Biophys. Acta. 29: 587.

34. Berman, J. D., and M. Young. 1971. Rapid and complete purification of acetylcholinesterase of electric eel and erythrocyte by affinity chromatography. Proc. Nat. Acad.Sci. U.S. A. $68: 395$. 
35. Mills, L. 1960. Dinitro-phenyl amino acids. In Chromatographic and Electrophoretic Techniques. I. Smith, editor. Interscience Publisher, Inc. New York. 2nd edition. 143.

36. Smith, T. W., V. P. Butler, Jr., and E. Haber. 1970. Characterization of antibodies of high affinity and specificity for the digitalis glycoside digoxin. Biochemistry. 9: 331

37. Nomoto, M., Y. Narahashi, and M. Murakami. 1960. A proteolytic enzyme of Streptomyces griseus. VI. Hydrolysis of protein by Streptomyces griseus protease. $J$. Biochem (Tokyo). 48: 598.

38. Koch-Weser, J. 1963. Effect of rate changes on strength and time course of contraction of papillary muscle. Amer. J. Physiol. 204: 451.

39. Blinks, J. R. 1965. Convenient apparatus for recording contractions of isolated heart muscle. J. Appl. Physiol. $20: 755$.

40. Koch-Weser, J. 1965. Role of norepinephrine release in the interval-strength relationship of heart muscle. J. Pharmacol. Exp. Ther. 150: 184.

41. Blinks, J. R. 1966. Field stimulation as a means of effecting the graded release of autonomic transmitters in isolated heart muscle. J. Pharmacol. Exp. Ther. $151: 221$.

42. Lowenstein, J. M. 1965. A method for measuring plasma levels of digitalis glycosides. Circulation. 31:228.

43. Akera, T., F. S. Larsen, and T. M. Brody. 1969. The effect of ouabain on sodium- and potassium-activated adenosine triphosphatase from the hearts of several mammalian species. J. Pharmacol. Exp. Ther. 170: 17.

44. Akera, T., and T. M. Brody. 1968. Inhibition of brain sodium- and potassium-stimulated adenosine triphosphatase activity by chlorpromazine free radical. Mol. Pharmacol. 4: 600 .

45. Fiske, C. H., and Y. Subbarow. 1925. The colorimetric determination of phosphorus. J. Biol. Chem. 66: 375 .

46. Dunham, P. B., and J. F. Hoffman. 1970. Partial purification of the ouabain-binding component and of $\mathrm{Na}$, K-ATPase from human red cell membranes. Proc. Nat. Acad. Sci. U.S. A. 66: 936.

47. Brown, B. T., and S. E. Wright. 1960. Absorption spectra of cardiac glycosides and aglycones in sulfuric acid. J. Amer. Pharm. Ass. 49: 777.

48. Wilson, W. D., and J. F. Foster. 1971. Conformation dependent limited proteolysis of bovine plasma albumin by an enzyme present in commercial albumin preparations. Biochemistry. 10: 1772.

49. Schwert, G. W. 1957. Recovery of native bovine serum albumin after precipitation with trichloroacetic acid and solution in organic solvents. J. Amer. Chem. Soc. $79: 139$.

50. Skou, J. C. 1969. The role of membrane ATPase in the active transport of ions. In The Molecular Basis of Membrane Function. D. C. Tosteson, editor. Prentice-Hall, Inc. Englewood Cliffs, N. J. 455.
51. Whittam, R., and K. P. Wheeler. 1970. Transport across cell membranes. Annu. Rev. Physiol. 32: 21.

52. Klaus, W., and K. S. Lee. 1969. Influence of cardiac glycosides on calcium binding in muscle subcellular components. J. Pharmacol. Exp. Ther. 166: 68.

53. Chipperfield, D., and W. G. Nayler. 1969. The effect of ouabain on calcium in subcellular fractions of cardiac muscle. J. Pharmacol. Exp. Ther. 170: 311 .

54. Koch-Weser, J. 1967. Mechanism of digitalis action on the heart. N. Engl. J. Med. 277: 417, 469.

55. Langer, G. A., and S. D. Sarena. 1970. The effects of strophanthidin upon contraction and ionic exchange in rabbit ventricular myocardium: relation to control of active state. J. Mol. Cell Cardiol. 1: 65 .

56. Besch, H. R., Jr., and A. Schwartz. 1970. On a mechanism of action of digitalis. J. Mol. Cell Cardiol. 1: 195

57. Okita, G. T. 1969. Distribution, disposition and excretion of digitalis glycosides. In Digitalis. C. Fisch and B. Surawicz, editors. Grune \& Stratton, Inc., New York. 13

58. Glynn, I. M. 1957. The action of cardiac glycosides on sodium and potassium movements in human red cells. J. Physiol. (London). 136: 148.

59. Whittam, R., and M. E. Ager. 1964. Vectorial aspects of adenosine-triphosphatase activity in erythrocyte membranes. Biochem. J. $93: 337$.

60. Schwartz, A., H. Matsui, and A. H. Laughter. 1968. Tritiated digoxin binding to $\left(\mathrm{Na}^{+}+\mathrm{K}^{+}\right)$-activated adenosine triphosphatase: possible allosteric site. Scicnce (Washington). 160: 323

61. Allen, J. C., and A. Schwartz. 1970. Effects of potassium, temperature, and time on ouabain interaction with the cardiac $\mathrm{Na}^{+}, \mathrm{K}^{+}$-ATPase: further evidence supporting an allosteric site. J. Mol. Cell Cardiol. 1: 39.

62. Cuatrecasas, P. 1969. Interaction of insulin with the cell membrane: the primary action of insulin. Proc. Nat. Acad. Sci. U. S. A. 63: 450.

63. Crestfield, A. M., S. Moore, and W. H. Stein. 1963 The preparation and enzymatic hydrolysis of reduced and S-carboxymethylated proteins. J. Biol. Chem. 238: 622.

64. Okarma, T. B.. and S. M. Kalman. 1971. The surface interaction of digoxin and cultured heart cells. J. Gen. Physiol. $57: 246$

65. Cuatrecasas, P., and C. B. Anfinsen. 1971. Affinity chromatography. Methods Enzymol. 22: 345.

65. Cuatrecasas, P. 1970. Protein purification by affinity chromatography. J. Biol. Chem. 245: 3059.

67. Bobbit, J. M. 1956. Periodate oxidation of carbohydrates. Advan. Carbohyd. Chem. 11: 1.

68. Khym, J. X. 1963. The reaction of methylamine with periodate-oxidized adenosine $5^{\prime}$-phosphate. Biochemistry. 2: 344 .

69. Brown, D. M., and A. P. Read. 1965. Nucleotides. Part 49. The reduction of the adduct of periodate-oxidized adenosine- $5^{\prime}$-phosphate and methylamine. J. Chem. Soc. (London) . 5072. 